\title{
Inspector General James Barry MD: putting the woman in her place
}

\author{
Brian Hurwitz, Ruth Richardson
}

James Barry qualified in medicine at the University of Edinburgh in 1812, at the age of only 17 . Barry's MD thesis, in Latin, was on hernia of the groin. ${ }^{\prime}$ As its epigraph it had a quotation from the classical dramatist Menander, which urged the examiners: "Do not consider my youth, but whether I show a man's wisdom."

No one spotted the real meaning of these words, and Barry proceeded to walk the wards as a pupil dresser at the United Hospitals of Guy's and St Thomas's under the tutelage of Astley Cooper. In January 1813 Dr Barry was "examined and passed as a Regimental Surgeon" by the Royal College of Surgeons of London. ${ }^{3}$ Thus began a career that was to span almost half a century and take in half the globe and was to culminate in the rank of inspector general of hospitals in the British army.

\section{A revelation}

James Barry's life and career have since provided inspiration for several literary works, including biographies, ${ }^{35}$ at least four novels, ${ }^{6-10}$ and two plays. ${ }^{11}{ }^{12}$ The cause of this interest is not difficult to find. This "most skilful of physicians, and ... most wayward of men"'13 died at'14 Margaret Street, Marylebone, during the summer of 1865 . Shortly afterwards the following report appeared in the Manchester Guardian ${ }^{14}$ :

An incident is just now being discussed in military circles so extraordinary that, were not the truth capable of being vouched for by official authority, the narration would certainly be deemed absolutely incredible. Our officers quartered at the Cape between fifteen and twenty years ago may remember a certain Dr Barry attached to the medical staff there, and enjoying a reputation for considerable skill in his profession, especially for firmness, decision and rapidity in difficult operations. This gentleman had entered the army in 1813 , had passed, of course, through the grades of assistant surgeon and surgeon in various regiments, and had served as such in various quarters of the globe. His professional acquirements had procured for him promotion to the staff at the Cape. About 1840 he became promoted to be medical inspector, and was transferred to Malta. He proceeded from Malta to Corfu where he was quartered for many years. . . and upon his death was discovered to be a woman. The motives that occasioned, and the time when commenced this singular deception are both shrouded in mystery. But thus it stands as an indubitable fact, that a woman was for forty years an office in the British service, and fought one duel and had sought many more, had pursued a legitimate medical education, and received a regular diploma, and had acquired almost a celebrity for skill as a surgical operator.

As a result of the article the then Registrar General requested further information from the certifying doctor, David McKinnon, as to the truth of rumours concerning Barry's sex. McKinnon replied that he had not examined the body and had no "purpose in making the discovery as I could positively swear to the identity of the body as being that of a person whom I had been acquainted with as Inspector General of Hospitals for a period of eight or nine years." "'McKinnon had merely

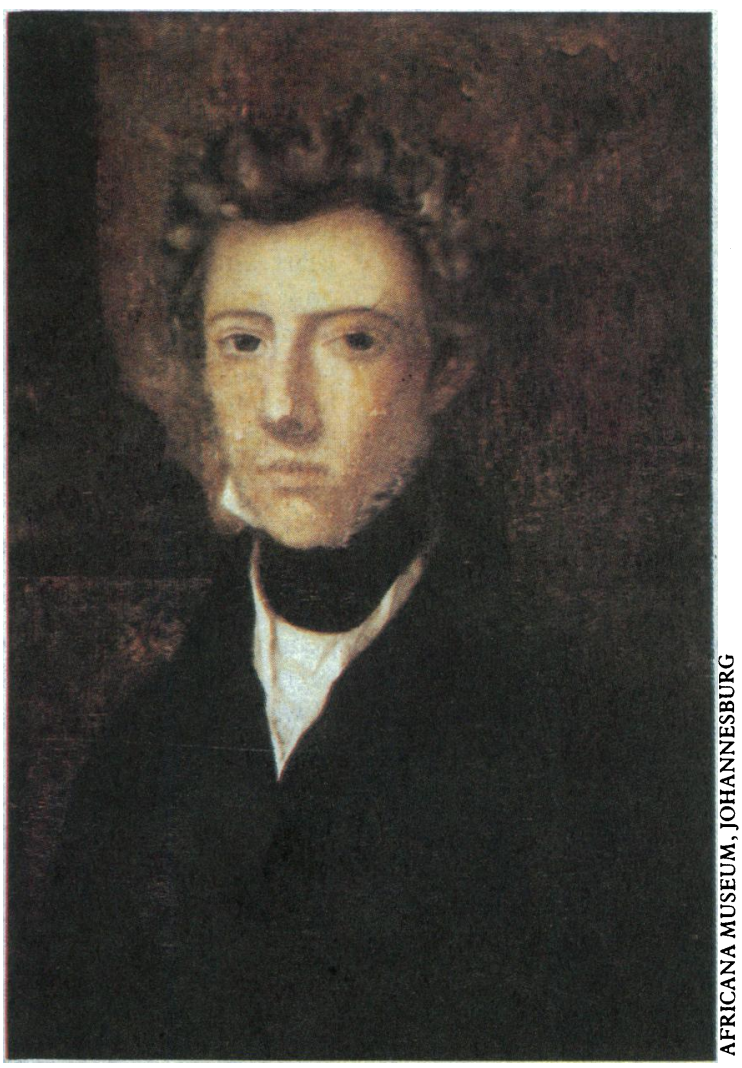

Fames Barry as a young man, from a portrait miniature on ivory.

certified the cause of death as "diarrhoea." 16 His reluctance to examine the corpse may be explained by the fact that Barry died during an epidemic. ${ }^{5}$ The local nurse who laid the body out had no such qualms and, as a result of a dispute concerning payment for her work, revealed the startling facts to Barry's army agents. There followed a confrontation at their office in St James's, which McKinnon described thus ${ }^{15}$ :

The woman who performed the last offices for Dr Barry was waiting to speak to me.... Amongst other things she said that Dr Barry was a female and that I was a pretty Doctor not to know this, and that she would not like to be attended by me... she had examined the body and... it was a perfect female.

By this time the story had gained its own momentum, and the Guardian's copy, which had itself originated in a Dublin newspaper, ${ }^{17}$ reappeared with additions in the Medical Times and Gazette under the title "A female medical combatant." 18 The editor of the British Medical Fournal also reprinted the story and commented "The gentleman alluded to was well known to many members of the profession. It was always suspected by those who knew him well in the army that he was a she." Within a week a denial appeared in the Medical Times and Gazette, which asserted, "The stories which have been circulated... are too absurd to be gravely refuted." ${ }^{20}$ The writer was a colleague who, like 
McKinnon, put forward what was to become an accepted apologia - that Barry was male or, if not, perhaps a hermaphrodite.

\section{The secret is kept}

The evidence, however, points in another direction. As a French medical journal commented at the time, "the enshrouders themselves were mothers of families ... who had seen, examined, and touched." ${ }^{21}$ Colleagues and patients throughout Barry's military career had noticed her feminine appearance and manner, and on at least one occasion Barry's sex was literally revealed. While she was seriously ill with yellow fever in Trinidad in 1841 two of her medical subordinates entered her sickroom to pry and, finding Barry asleep, turned back the bedclothes ${ }^{22}$.

At that moment the P.M.O. awoke to consciousness and gazed at us bewilderingly. But she quickly recovered presence of mind, and asked us in low tones to swear solemnly not to disclose her secret as long as she lived.

How Barry persuaded these men to respect her secret is not known, but this witness kept his silence for 15 years after Barry's death and revealed the discovery only after the publication of a novel about her life. $A$ Modern Sphinx appeared in 1881 as a triple decker novel. ${ }^{6}$ As a young man its author, Ebenezer Rogers, had shared a cabin with Barry on board a Caribbean steamer: "A goat was on board to provide her with milk; she was a strict vegetarian, and she was accompanied by a negro servant and a little dog." ${ }^{23}$

Throughout her career Barry used, with varying success, techniques to disguise her real sex, and Rogers came to appreciate only retrospectively that her behaviour had involved rituals of concealment as well as eccentricity. He recalled later in a letter to the Lancet: "I well remember how in harsh and peevish voice, she

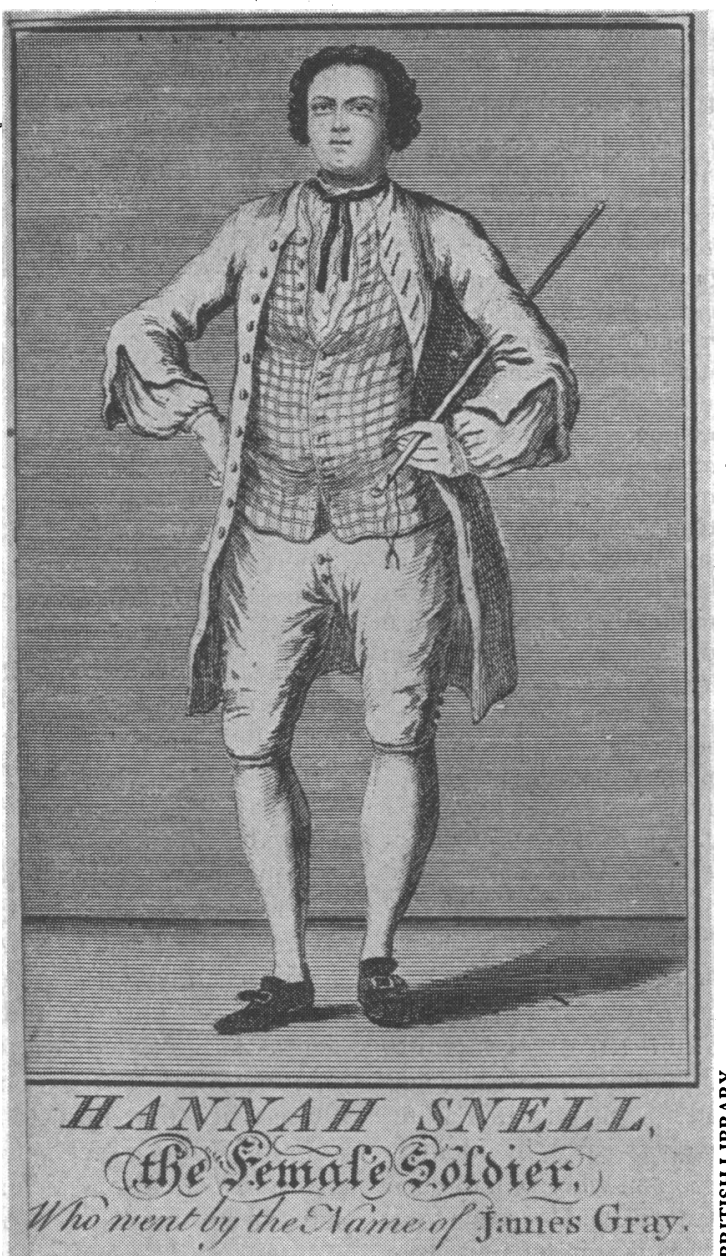

ordered me out of the cabin-blow high, blow lowwhile she dressed in the morning. 'Now then, youngster, clear out of my cabin while I dress,' she would say." ${ }^{23}$ Another colleague observed that Barry "always took care never to be seen . . . like any ordinary man," ${ }^{24}$ a reference to her need for privacy to conceal bodily functions.

At the same time, again with varying success, Barry asserted an apparent masculinity. In the Cape her shoulder pads gave rise to the sobriquet "Kapok Doctor," subject of comment. ${ }^{20}$ She adopted a seriousness of manner that many found off putting and was quick to take offence: "He was always suspected of being a female from his effeminate features and voice, and having neither beard nor whiskers. He was a very bold person, and challenged one or two of our officials for naming him a diminutive creature. ${ }^{24}$

\section{Playing the breeches part}

The simultaneous concealment of femininity and assertion of masculinity evident in James Barry's case are found in other instances in which women have adopted male dress to achieve an independent life outside the home. Many cases of this sort of cross dressing, unrelated to sexual proclivity ${ }^{26}$ are recorded in the eighteenth century. A well documented example is that of Hannah Snell, born in 1723, who took male dress for safety to search for the husband who had deserted her. She joined the army under the name of James Gray and established a reputation for "courage, skill and intrepidity," suffering severe wounds at the battle of Pondicherry (in India) in 1748. On returning to England she revealed her sex, but by then had come to prefer male attire. She later established a public house at Wapping, which she named "The Widow in Masquerade, or the Female Warrior," and subsequently married again. Despite having her memoirs published during her lifetime Hannah Snell was maintained as a Chelsea pensioner until her death in 1792. 27 Another ex-soldier, Phoebe Hessel, was wounded in the battle of Fontenoy (in Austria) in 1745 Her gravestone in the churchyard of St Nicholas, Brighton, records that until her death in 1821 she was honoured with a pension granted personally by the Prince Regent.

Plays featuring "travestied roles," in which women played the parts of men, became popular in the eighteenth century. Perhaps the most famous actress to play breeches parts was Peg Woffington, who performed in front of the Prince and Princess of Wales in $\mathbf{1 7 4 2}$ and whom Garrick acknowledged as a male rival. The public reacted to her performances with enthusiasm ${ }^{29}$ :

\section{That excellent Peg}

Who showed such a leg

When lately she dressed in men's clothes-

A creature uncommon

Who's both man and woman

And chief of the belles and the beaux

The actress Charlotte Charke crosś dressed off stage as well as on it, and in 1755 published memoirs of her adventures dressed in men's clothes. ${ }^{29}$ In the second half of the eighteenth century temporary cross dressing became an accepted fashion with the popularity of masquerades. One historian has noted that such "sartorial transformation" offered women "a cathartic escape from the self" and a "suggestive revision of ordinary experience." 30

Some women adopted an entirely male identity to achieve success in occupational roles otherwise closed to them. ${ }^{26}{ }^{31}$ In the eighteenth century such behaviour was tolerated to a degree, even when it became public knowledge. The historian Lynne Friedli has docu-
Hannah Snell, the frontispiece of her autobiography published in 1750 
mented the lives of 34 women who lived as men during the eighteenth century. Of these, 16 were soldiers, sailors, or pirates. A further five lived as single men following various professions, who were discovered and not prosecuted. She comments: "Women who cross-dressed generally gained the higher social and economic status associated with being male. They had access to occupations that were limited to men, notably in the military field. In addition, dressed as men they enjoyed greater mobility and employment prospects, with better pay." 26

\section{Parentage and patronage}

Barry was born at the very end of the eighteenth century, in about 1795. Hannah Snell had died only two years before, and Phoebe Hessel was still selling gingerbread on the front at Brighton..$^{32}$ During Barry's adolescence the most celebrated case of cross dressing was even nearer home. The sex of the Chevalier d'Eon, a French diplomat in London, was the subject of betting among regency fops. Many suspected d'Eon of being a woman who intermittently dressed as a man. At his death in 1810 the opposite was found to be the case. ${ }^{3133}$ So great was the interest in the Chevalier's sex that one of his testicles was removed and was later purchased at auction by the Royal College of Surgeons for the sum of ten shillings and sixpence. ${ }^{34}$

Barry's parentage remains a mystery. What is known suggests that she was probably the niece of the artist James Barry RA, whose name she adopted. Her two middle names, Miranda and Steuart, were taken from her influential sponsors, General Francisco de Miranda, a Venezuelan revolutionary patriot and scholar, and David Steuart Erskine, Lord Buchan, art collector and savant. Both men were close friends of the artist and enlightened supporters of female education. ${ }^{35}$ Barry acknowledged her debt to both men in the dedication to her MD thesis. ${ }^{1}$

Just before Barry's birth Lord Buchan had written a series of essays in The Bee, a periodical designed for the edification and entertainment of young ladies. These essays were republished in book form in Edinburgh in 1812 while Barry was studying medicine there. Buchan's essay On Female Education argued that in denying women education, his countrymen were guilty of the cerebral equivalent of Chinese foot binding. Significantly, Buchan wrote several of these essays in the guise of a woman, signing them "Sophia." 35

Lord Buchan certainly gave his patronage to James Barry during her medical education and may have introduced her to influential friends in the army medical service. ${ }^{35}$ Ebenezer Rogers believed that she probably "possessed ... backdoor influence" as her promotion was rapid, and "she even managed to jump up, two steps at a time, in her ambitious climb to the top of the tree." 6

\section{A reforming doctor}

But Barry's army service records a string of impressive achievements, which in themselves account for her advancement. Her army duties often extended beyond the confines of military medicine into the communities in which she served. As a surgeon she is credited with the first successful caesarean section in South Africa in 1826 - one of the earliest recorded cases in the world in which both mother and child survived. ${ }^{36-38}$ Barry conducted experiments into the medicinal value of local plants in treating syphilis ${ }^{39}$ and on preventing corrosion in pipes carrying fresh water. ${ }^{36}$ She received the personal thanks of the Duke of Wellington for her work in Malta during an outbreak of cholera in 1846 and was promoted shortly afterwards to deputy inspector general. ${ }^{40}$

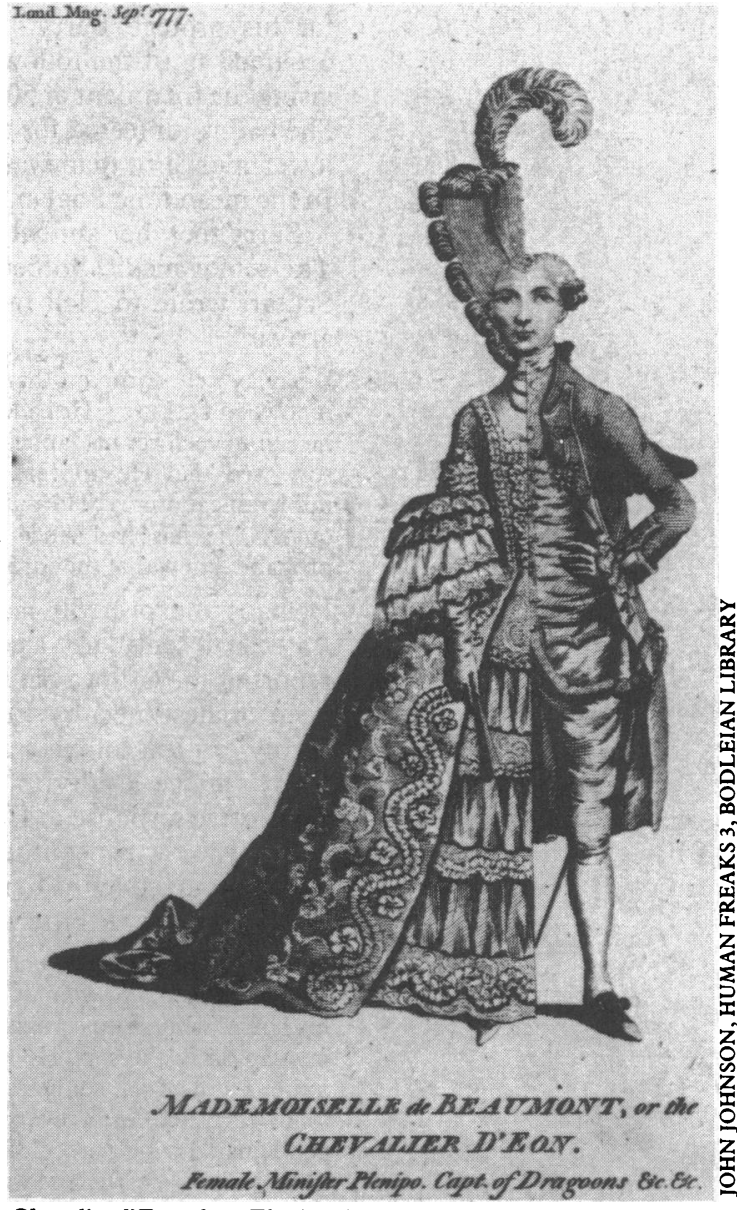

Chevalier d'Eon, from The London Magazine, September 1777

In her colonial postings James Barry gained a formidable reputation as a doctor and administrator who challenged the power of local oligarchies and would not brook corrupt or negligent practices. She drew up clear and humane rules for treating inmates in the Cape leper colony, protested about brutality towards prisoners, and attempted to control the sale to the general public of spurious and dangerous medicines. ${ }^{364}$ On one occasion, to prevent an epidemic of sunstroke among men of the 71st Highland Light Infantry, she convened a medical board to declare its colonel non compos mentis for drilling the men in the midday sun. A soldier later recalled that the regiment subsequently embarked for the Crimea, followed by its colonel, "who persistently applied to Lord Raglan to be restored to command. His services, however, were declined, much to the satisfaction of the men." "A2 An officer later remarked: "Although it is quite certain that for these 'interfering ways' many of the senior officers disliked Barry, there must be still many officers and a great many of the ex-rank and file who remember her with gratitude." ${ }^{43}$

\section{Conflict in the Crimea}

At the outset of her army medical career Barry had been appointed physician to Raglan's brother Lord Charles Somerset, then governor of the Cape. She had saved the life of one of his daughters and had become a favourite with the family. ${ }^{35}$ Lord Raglan, then commander in chief of the British forces in the Crimea, thus had reason to respect her medical skill. Had Barry been appointed inspector general of hospitals in the Crimea the medical history of the war might have been altogether different. Such a notion is not merely fanciful: the beleaguered incumbent of that office, Sir John Hall, confided to his diary late in $\mathbf{1 8 5 4}$ his fcars that Raglan wanted to "get rid" of him to "make room 
for his protégé Barry." ${ }^{45}$ In fact Barry was fully occupied until the following autumn in Corfu supervising the treatment of 500 casualties from the Crimea. She had volunteered for the task and achieved a much lower mortality than was ever recorded in Scutari. ${ }^{540}$ In the mean time Raglan had died.

Barry took her annual leave in the Crimea in 1855. The senior medical officer at the Barrack Hospital in Scutari wrote to Hall to warn him of her imminent arrival ${ }^{46}$ :

I may as well warn you that you are to have a visit from the renowned Dr Barry. He called on me yesterday and as I never met him before his appearance and conversation rather surprised me. He appears to be in his dotage and is an intolerable bore.... He will expect you to listen to every quarrel he has had since coming into the Service. You probably know that they are not a few.

Perhaps unexpectedly Hall and Barry became friends. Later Hall sent Barry a copy of his Observations on the report of the Crimea Sanitary Commission, which had been orchestrated by Florence Nightingale and was highly critical of the army medical department. ${ }^{47}$ Barry's fierce loyalty to the service is evident in her supportive response to Hall's manuscript ${ }^{48}$ as it was in her only known encounter with Florence Nightingale, which occurred in the Crimea. Nightingale was later to recall it with some bitterness ${ }^{49}$ :

I never had such a blackguard rating in all my life - I who have had more than any woman - than from this Barry sitting on his horse, while I was crossing the Hospital Square with only my cap on in the sun. He kept me standing in the midst of quite a crowd of soldiers, Commissariat, servants, camp followers, etc., etc., every one of whom behaved like a gentleman during the scolding I received while (she) behaved like a brute. ... After she was dead, I was told that (he) was a woman.... I should say that (she) was the most hardened creature I ever met.

\section{A vale of tears}

The careers of two extraordinary nineteenth century women intersect at this point. Each had chosen a different path by which to transcend the limitations imposed upon her sex. Both had rejected traditional female social and familial roles. ${ }^{31}$ In 1855 both were women in a man's world whose chosen strategies reflected different ambitions: James Barry had joined an existing professional structure and achieved piecemeal reforms from within, Florence Nightingale had determined to create an entirely new structure. In the Crimea Barry could exercise rank and power over Nightingale, but she probably had little notion how profoundly her own future career would be affected by the younger "lady with the lamp." Florence Nightingale's determination to reform the army medical department, and her contempt for Sir John Hall, the next in line for promotion to director general, resulted after much political chicanery in the appointment of Sir Thomas Alexander, then serving in Canada. ${ }^{50}$ Barry was sent out as his replacement, promoted to inspector general of hospitals. ${ }^{+}$She wrote to a colleague ${ }^{\text {s1 }}$ :

So I am to go to Canada, to cool myself after such a long residence in the Tropics and Hot Countries... This much for changes and chances in this 'World of woe, this Vale of Tears' as schollars say.

Nevertheless, Barry arrived in Canada with her old reforming zeal intact and, despite the freezing weather, set about improving soldiers' diet, accommodation, and water supplies. She recommended the establishment of separate quarters for married servicemen and recreational facilities such as libraries and athletics for all ranks. ${ }^{5}$ Barry was by now 64 years old and had worked for 40 years in the tropics. The Canadian winters affected her health, and in 1859 she caught influenza, developed bronchitis, and returned sick to London in a weak state. ${ }^{52}$

Barry's Canadian physician, Dr G W Campbell, later became dean of McGill Medical School. His embarrassment at having failed to detect her sex, despite treating her for a chest complaint, was relished by his students, among them the young Osler, who later recalled that Campbell had told his class in mitigation $^{53}$ :

Gentlemen, if I had not stood in some awe of Inspector General Barry's rank and medical attainments, I would have examined him - that is, her-far more thoroughly. Because I did not and because his-confound it, her-bed-room was always in almost total darkness when I paid my calls, this, ah, crucial point escaped me.

On her return to London Barry appeared before a medical board and was pronounced unfit for further service. Although she petitioned the Secretary of State for War ${ }^{40}$ she was retired from the army medical service on half pay in July 1859 , her sex still undiscovered.

\section{Reluctant retirement}

James Barry's reluctant retirement coincided with the flowering of the campaign to gain women's entry to medicine in Britain. The American trained doctor Elizabeth Blackwell had succeeded in January 1859 in being the first woman in Britain to have her name on the newly established medical register. That spring this "personification of therapeutics in crinoline" $"$ delivered a series of lectures on the medical education of women to an appreciative audience in London, which included the young Elizabeth Garrett Anderson. ${ }^{55}$

Elizabeth Blackwell's earlier applications to study medicine in American colleges had met with refusal, and she had been advised both by her private tutor and by the professor of surgery at Philadelphia to "don masculine attire to gain the necessary knowledge." The suggestion, she said, did not tempt her for a moment. "It was to my mind a moral crusade on which I had entered, a course of justice and common sense.. pursued in the light of day, and with public sanction, in order to accomplish its end." "ss She had eventually gained her MD in 1849 at Geneva College in New York State. ${ }^{56}$ Her younger sister, Emily, who also became a doctor, considered the expedient of adopting male attire to study m̈dwifery in Paris. ${ }^{50}$

In the $1850 \mathrm{~s}$, after Elizabeth Blackwell's achievement, many women qualified as doctors in America. ${ }^{5}$ The Female Medical College of Pennsylvania appealed in $\mathbf{1 8 5 8}$ for additional funds, saying that the medical education of women was "the necessity of the age, and a way-mark of the advancement of a refined civilisation." 58 In Britain things were more difficult During Barry's retirement Elizabeth Garrett obtained a medical training informally at several different British medical schools, none of which would accept her as a student or examine her formally for a qualification. ${ }^{59}$

Barry's views on Elizabeth Blackwell's lectures, and on the growing pressure for the medical education of women in the $1860 \mathrm{~s}$, are a rich subject for speculation. Sadly, no diary survives. After her retirement Barry settled in London, taking rooms in a dentist's house near Oxford Market, only a dozen doors away from the house in which her namesake, the artist, had lived and died. Here she was stricken with her last illness. Barry probably did not expect to die so swiftly. When ill on an earlier occasion, she had given directions that in the event of death she was to be buried in her clothes without further examination. ${ }^{24}$ No such request seems to have been observed in Marylebone in 1865. Instead, 


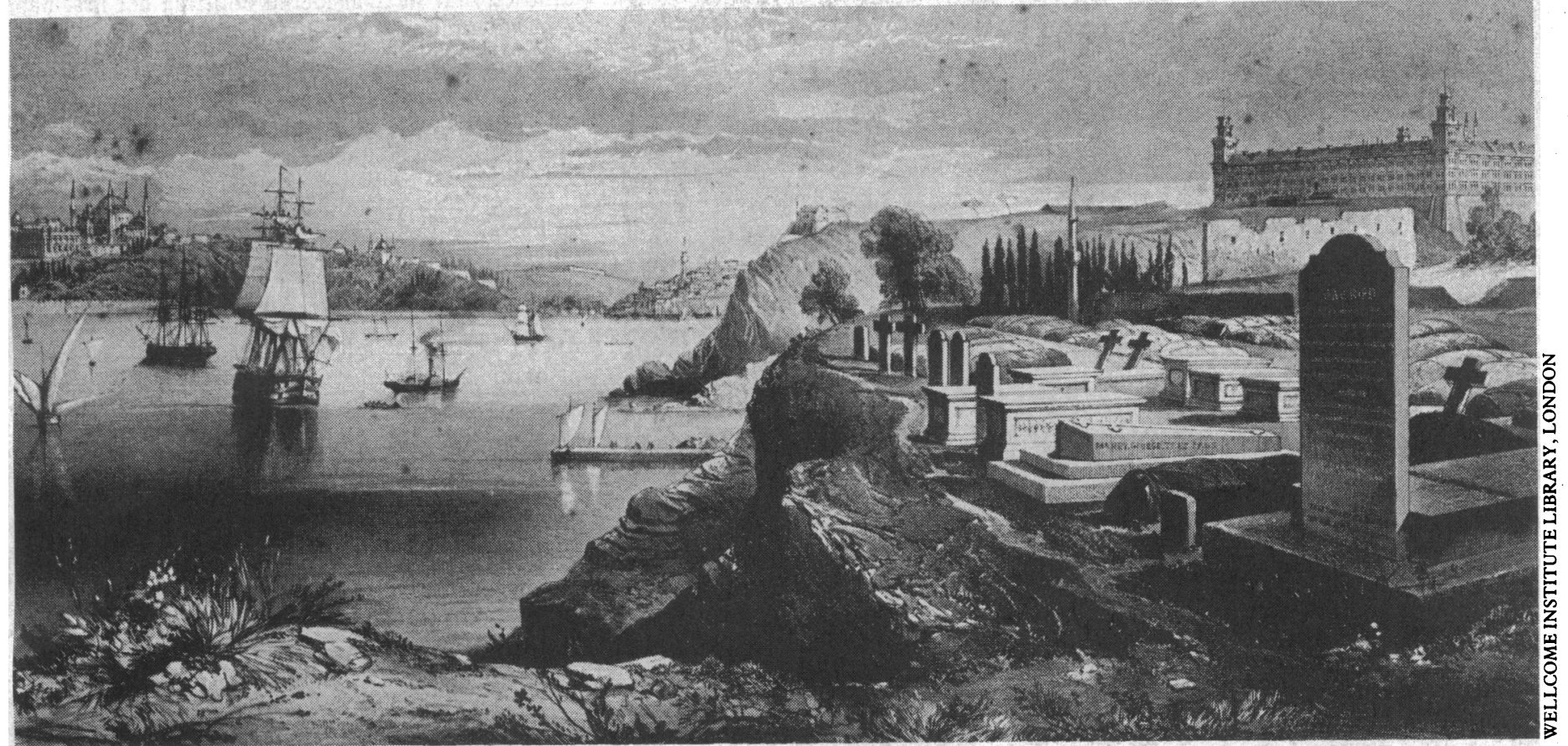

British hospital and burying ground, Scutari, 1864 as was customary, a local layer out was called in. ${ }^{60} \mathrm{~A}$ box containing Barry's personal possessions is said to have been collected by a servant in livery, but its contents have never been traced. ${ }^{61}$ Barry was buried at Kensal Green cemetery. ${ }^{62}$

\section{Achieving the unthinkable}

The year of Barry's death (1865) marked two other events important in the history of women's medical education. Dr Mary Walker, who had adopted male dress to serve as a doctor in the American civil war, was awarded the congressional medal of honour by Congress. The following year she delivered a series of public lectures in Britain on her experiences as a female doctor "in college, private practice and the Federal Army." "63

The year 1865 also saw Elizabeth Garrett qualify as a doctor by obtaining the licentiate of the Society of Apothecaries. She had faced enormous opposition in her attempt to gain a medical education and managed to sit the exams only by means of a loophole in their statutes and after her father had threatened the society with a lawsuit if it refused to examine her. ${ }^{59}$ Regulations governing admission to the Society of Apothecaries, like those to the Medical Register and the British Medical Association, made no reference to a candidate's sex. That a woman could obtain a medical education had hitherto seemed unthinkable. James Barry had achieved the unthinkable by stealth; Elizabeth Garrett did so openly.

The Society of Apothecaries, and later the BMA hurried to exclude any further female entrants by rewriting their regulations. ${ }^{59}$ Parliament, however, refused to do the same for the Medical Register and after a decade of controversy legislated to open medical and university education to women. ${ }^{64}$ When in 1876 the Royal College of Surgeons of England found itself confronted with female examinees because of specific legislation, ${ }^{65}$ an entire board of examiners resigned and was not replaced for a decade, thus preventing any exams from taking place. ${ }^{66}{ }^{67}$ Pressure for reform came from many quarters, not least among them female medical students in Edinburgh, led by Sophia Jex Blake. Despite the new legislation Edinburgh was intransigent in its refusal to examine women, who went instead to the College of Physicians in Dublin to obtain a registerable qualification. ${ }^{68}$
What Edinburgh and London denied these women in the 1870s James Barry had achieved 60 years earlier. The irony did not go unnoticed. In his textbook of medical jurisprudence published in 1873, Alfred Swaine Taylor used Barry's life to exemplify the phenomenon of "concealed sex." $\mathrm{He}$ commented somewhat mischievously: "With such a successful precedent before them the examining board of Edinburgh are hardly justified in excluding women from professional study and examination." ${ }^{69}$

\section{Posthumous fictions}

Later in the century, when they came to write their histories of women in medicine, both Sophia Jex Blake and Elizabeth Garrett Anderson failed to mention Barry's achievement.$^{6470}$ Barry was probably not deliberately omitted but simply overlooked as both writers were keen to cite successful precedents for their own attainments, and Jex Blake noted the earlier case of the ancient Athenian Agnodice, "a noble maid" who dressed "like a man" to become "a scholar of ... the most learned physician of the time."

These and other influential supporters of women's medical education were either unaware of Barry's "singular deception" or doubted its veracity. ${ }^{72} 73$ James Barry's life began to be fictionalised soon after she was buried. None of the national papers had published an obituary or commented on her achievements, and the coverage offered by provincial papers was in many respects inaccurate. When the subjeçt emerged again in 1867 in a popular weekly journal conducted by Charles Dickens it was as a short story with the title $A$ Mystery Still, larded with erroneous information and imaginary dialogue. ${ }^{74}$

It was Dickens who first assumed that Barry's last offices had been undertaken by a "charwoman." Dickens's derogatory view of the domiciliary nurse, personified in his character Sarah Gamp, helped Florence Nightingale's campaign to gentrify and professionalise nursing. Dickens's hint was taken up by Barry's later biographers. ${ }^{35}$ One assumed that the layer out was the illiterate house servant, Sophia Bishop, who registered Barry's death, leaving her mark in the Marylebone death register. Another pictured the woman as an original Sarah Gamp, "the sort of nurse who put the gin bottle on the mantelpiece and placed her lips to it when 'she was so dispoged." "75 76 


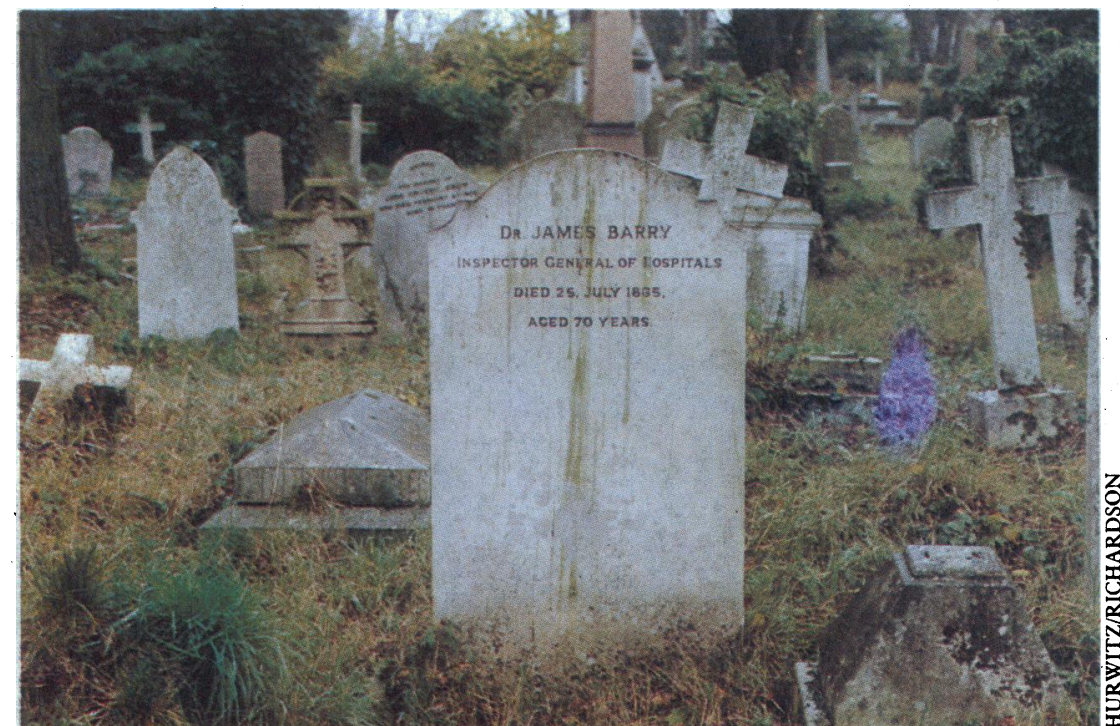

Grave (No 19301/67/6) at

Kensal Green cemetery, London

In fact the layer out was the mother of nine children ${ }^{15}$ and therefore unlikely to have been the house servant at 14 Margaret Street, who was recorded in census returns as only 30 years old and unmarried. ${ }^{77}$ The certifying doctor, David McKinnon, who met the layer out in question, wrote nothing to the detriment of her appearance or skill; though he had ample cause and opportunity to do so.

Fiction also attached itself to James Barry. The nature of her story and the lack of information about her life encouraged fantasy by later enthusiasts. A sentimental love story was constructed to explain her entry into medicine, a drunken husband invented to account for the need for a new identity, and the name of her supposed lover became the subject of conjecture..$^{11378}$ Such concoctions still appear from time to time. ${ }^{12}$ This process has had the beneficial result of keeping her memory alive and in the past occasionally gave rise to correspondence from those who had actually known Barry or whose parents had passed on their memories. In South Africa Barry remained a subject of interest, and her endeavours have been accorded serious consideration..$^{36} 79.82$

\section{A female tradition}

It was Isabel Rae's discovery in the 1950s of an army archive in London that marked a turning point in Barry's posthumous biography. ${ }^{83}$ These papers provided much of the basis for the two biographies that have since been published. ${ }^{35}$ Yet in spite of the biographers' evident sympathy and respect for James Barry, to both she remained an intriguing aberration rather than a manifestation of a long standing female tradition. Her life embodied a well used strategy that many women adapted to their own purposes in different epochs. The adoption of male identity was a compromise that some ambitious women historically were prepared to make to achieve what contemporary norms of femininity precluded. Vestiges of the same strategy survived in the adoption of male pseudonyms by nineteenth century writers such as the Brontës and Mary Ann Evans (George Eliot).

By the 1890 s opposition to the medical education of women had been officially overcome. The Practitioner announced: "The walls of the medical Jericho are everywhere falling," ${ }^{84}$ and the British Medical Fournal commented: "It is almost as easy at this moment for a woman to get a complete medical education in England, Scotland or Ireland, as it is for a man." ${ }^{85}$ Such comments seem to us to have been premature by almost a century. ${ }^{86-88}$ A consultant surgeon recently admitted that she considered omitting her first name from an application form in order to conceal her sex from a selection panel. ${ }^{89}$

Historically James Barry's career marks an important transition. Her life spans the period between Hannah Snell's incognito army career and the frank rejection of subterfuge by Elizabeth Blackwell. Unlike Florence Nightingale and Elizabeth Garrett Anderson, whose public attainments were widely known in their time and are still appreciated today, James Barry never intended to publicise her achievement as Britain's first woman $M D$, and she remains little known. Although the Royal Army Medical Corps maintains a committee room in her name, no public plaque or statue commemorates her life. The hospital ward once named after her at the Queen Alexandra Military Hospital, Millbank, was closed in 1977.

Excerpts from documents of the Royal Army Medical Corps are reproduced by courtesy of the Trustees of the Royal Army Medical Corps Museum, Wellcome Tropical Institute Archive, London. We thank Colonel Eyions, director, Royal Army Medical Corps Museum, Aldershot, for his help and advice; Shirley Taylor, assistant archivist, Wellcome Tropical Institute, for help in consulting these papers; the military historian Mr Edward Boys; the Africana Museum, Johannesburg; the British Library Reading Room, London; the Bibliotheca Osleriana, McGill Univérsity, Montreal; Woodward Medical Library, University of British Columbia, Vancouver; and the Royal College of Physicians, London.

1 Barry J. Disputatio medica inauguralis de merocele, vel hernia crurali. [MD dissertation.] Edinburgh: C Stewart, 1812 .

2 Barry J. Disputatio medica inauguralis de merocele, vel hermia crurali. Edinburgh: C Stewart, 1812. (Excerpt translated by Appleton EV. The Times 1954 June $17: 7(\operatorname{col} 5)$.

3 Rae I. The strange story of Dr fames Barry. London: Longmans, 1958:17; $2-10 ; 35 ; 46 ; 115$

4 Drew WRM. Commissioned officers in the medical services of the British army. Vol 1. London: Wellcome, 1968:242.

5 Rose J. The perfect gentleman. London: Hutchinson, 1977:14;17-21;52;57;139; 144-48;152.

6 Rogers E. A modern sphinx. London: Maxwell, 1881 and 1895: Vol 1;iv.

7 Braddon ME. Madeline's mystery. London: Maxwell, 1882.

8 Juta R. The tavern. London: Heinemann, 1920.

8 Juta R. The tavern. London: Heinemann, 1920.

9 Racster O, Grove J. Dr fames Barry, her secret story. London: Howe, 1932.
10 Racster O, Grove J. The journal of Dr fames Barry. London: Bodley Head, 1932.

11 Racster O, Grove J. Dr fames Barry, a romantic play founded on South African history. (Unpublished.) London: British Museum. (Manuscript collection of Lord Chamberlain's plays. vol 17.) (performed at St James's Theatre on 22 July 1919 with Sybil Thorndike as Barry.

2 Thornber R. Double firsts. Guardian 1988 Sep 30:31 (cols 1-6)

13 Keppel GT (Earl of Albermarle). Fifty years of my life. Vol 2. London: Macmillan, 1876:96.

14 Anonymous. Manchester Guardian 1865 Aug 21:3 (col 7).

15 McKinnon DR. Letter to G Graham, Registrar General. 24 August 1865. London: Wellcome Tropical Institute Archive. Royal Army Medical Corps collection; catalogue No 373.

16 James Barry's death certificate No 4883: 26 July 1865. General Register Office, Marylebone District. (Reproduced in: Racster O, Grove J. The journal of $D_{r}$ fames Barry. London: Bodley Head, 1932: endpapers.)

17 Anonymous. From our own correspondent. Saunders's News-letter and Daily Advertiser 1865 Aug 14:1 (col 7); 2 (col 1).

18 Anonymous. A female medical combatant. Medical Times and Gazette 1865 ii:227-8.

19 Markham WO. A female medical army inspector. Br Med f 1865; ii: 249

20 Bradford E. The reputed female army surgeon. Medical Times and Gazett 1865;ii:293.

21 La revue des médicins des armées de terre et de mer. (c 1865.) Sir Thomas Longmore's collection of papers. London: Wellcome Tropical Institute Archive. Royal Army Medical Corps collection; catalogue No 238.

22 Rogers E. A female member of the army medical staff. Lancet 1895;ii: 1269.

23 Rogers E. A female member of the army medical staff. Lancet 1895;ii:1021.

24 McCowan RT. The late Dr Barry. Whitehaven News 1865 Sept 7:4 (col 5).

25 Green LG. Grow lovely, growing old: the story of Cape Town's three centuries. Cape Town: Timmins, 1951:114.

26 Friedli L. "Passing women"-a study of gender boundaries in the eighteenth century. In: Rousseau GS, Porter R, eds. Sexual underworlds of the century. In: Rousseau GS, Porter R, eds. Sexual underworlds of

27 enlightenment. Manchester: Manchester University Press,

28 Snell $\mathrm{H}$. The female soldier or, the life and adventures of Hannah Snell. London: Bentley, 1750 .

29 Rogers P. The breeches part. In: Bouce PG, ed. Sexuality in eighteenth-century Britain. Manchester: Manchester University Press, 1982:250.

30 Castle T. The culture of travesty: sexuality and masquerade in eighteenth century England. In: Rousseau GS, Porter R, eds. Sexual underworlds of the enlightenment. Manchester: Manchester University Press, 1987:157.

31 Ackroyd P. Dressing up. New York: Simon and Schuster, 1979:71-82.

32 Musgrave C. Life in Brighton. Rochester: Rochester Press, 1981: 164-5.

33 Bullough VL. Transsexualism in history. Archives of Sexual Behaviour 1975;4:562-3.

34 Peachey GC. Fohn Heaviside, surgeon. London: St Martin's Press, 1931:25.

35 Erskine DS. The anonymous and fugitive essays of the Earl of Buchan collected from various periodical works. Edinburgh: Ruthven, 1812. 
36 Laidler PW, Gelfand M. South Africa: its medical history 1652-1898. Cape Town: Struick, 1971:132-204.

37 Russell MP. James Barry inspector general of army hospitals. Edin Med f 1943;50:560-1

38 Kerr JM. Historical review of British obstetrics and gynaecology. Edinburgh: Oliver and Boyd, 1954:31-32.

39 Barry J. Report on the Arctopus echinatus or Plat Doorn of the Cape of Good Hope. Reprinted in: James T. Sieketroost: Dr James Barry's contribution to materia medica. $S$ African Med J 1972;46:1013-6.

40 Barry J. The humble memorial of Dr fames Barry, inspector general of hospitals, to the Rt Hon Secretary of State for War. (c 1858-9.) London: Wellcome Tropical Institute Archives. Royal Army Medical Corps collection; catalogue No 373 .

41 Barry J. Reports and letters. In: Theal GM. Records of the Cape Colony. London: 1897-1905;17:245-6;23:91-2;498-508.

42 Hutchinson RF. Letter in unidentified Jamaican newspaper. (c July 1897 .) London: Wellcome Tropical Institute Archive. Roval Army Medical Corps collection; catalogue No 238 .

43 'JCP'. Letter in unidentified Jamaican newspaper. (c July 1897.) London: Wellcome Tropical Institute Archive. Royal Army Medical Corps collection; catalogue No 238 .

44 Cantlie N. A history of the army medical department. Vol 2. London: Churchill Livingstone, 1974:113-4.

45 Hall J. Diary, entry dated 17.12.1854. London: Wellcome Tropical Institute Archive. Royal Army Medical Corps collection; catalogue No 937.

46 Cumming A. Letter to Sir John Hall 16.10.1855. London: Wellcome Tropical Institute Archive. Royal Army Medical Corps collection; catalogue No 238. 7 Hall J. Observations on the report of the Crimea Sanitary Commission. London: W Clowes, 1857

48 Barry J. Letter to Sir John Hall 25.9.1857. London: Wellcome Tropical Institute Archive. Royal Army Medical Corps collection; catalogue No 937.

49 Nightingale F. Letter to Parthenope, Lady Verney. (Undated, after July 1865.) London: Wellcome Institute for the History of Medicine.

50 Woodham-Smith C. Florence Nightingale 1820-1910. London: Constable, 1950;87-88;311-2;384

51 Barry J. Letter to W Bell, 3.8.1857. London: Wellcome Tropical Institute Archive. Royal Army Medical Corps collection; catalogue No 1264

52 Barry J. Memorandum of the service of Dr James Barry, inspector general of Aarry J. Memorandum of the servece of Dr fames Barry, inspector general of hospitals. (Undated.) London: Wellcome Tropical Institute Archive. Royal Army Medical Corps collection; catalogue No 373.

Osler W. Quoted in MacMahon JR. Dr James Barry: a study in deception. MacGill Medical foumal 1968;37:25-32.

54 Gillie A. Elizabeth Blackwell and the medical register from 1858. Br Med $\mathrm{J}$ 1958;ii: 1254

55 Blackwell E. Pioneer work in opening the medical profession to women. London: Longmans, 1895:61-2;218

56 Tripp W. Dr Elizabeth Blackwell's graduation-an eye-witness account. New York History 1962;43:182-5.

57 Walsh MR. "Doctors wanted": no women need apply. New Haven: Yale University Press, 1977.

58 Preston A. A valedictory address to the graduating class. Philadelphia: Female Medical College of Pennsylvania, 1858:16.

59 Manton J. Elizabeth Garrett Anderson. London: Methuen, 1965:146-63; $161-2 ; 176 ; 258-60$
60 Richardson R. Death, dissection and the destitute. London: Routledge, 1988 $17-21$

61 McCrindle JC. Dr James Barry. Glasgow Herald 1949. London: Wellcome Tropical Institute Archive. Royal Army Medical Corps collection; catalogue No 238.

62 Rogers E. The grave of Dr James Barry. Lancet 1910;ii:1115.

63 Brussel IA. Pants, politics, postage and physic. I'sychiatric Quarterly Supplement 1961;35:332-45.

64 Medical Act (Qualifications), 1876. (39 \& 40 Vict. c41.)

65 Medical Act: Royal College of Surgeons of England, 1875. (38 \& 39 Vict. c43.)

66 Lutzker E. Medical education for women in Great Britain. [MA dissertation. New York: Columbia University, 1959.

67 Scott JM. Women and the GMC. Br Med f 1984;289:1764-7.

68 Jex-Blake S. Medical women: a thesis and a history. Edinburgh: Oliphant, 1886

69 Taylor AS. Principles and practice of medical jurisprudence. Vol 2. London: Churchill, 1873:287.

70 Anderson EG. The history of a movement. Fortnightly Review 1893;March $1: 404-17$

71 Lloyd GER. Science, folklore and ideology: studies in the life sciences in ancient Greece. Cambridge: Cambridge University Press, 1983;70.

72 Markby T. Medical women. London: Harrison, 1869.

73 Stansfield J. Medical women. The Nineteenth Century 1877;5:888-901.

74 [Dickens C]. A mystery still. All the Year Round 1867;17:492-5.

74 [Dickens C]. A mystery still. All the Year Round 1867;17:492-5. department. Journal of the Royal Army Medical Corps 1939;73:106-20; $173-8 ; 240-8$.

76 Summers A. The mysterious demise of Sarah Gamp: the domiciliary nurse and her detractors c. 1830-60. Victorian Studies (in press).

77 General Register Office. HM Census 186l, Marylebone District. (Entry for 14 Margaret St. Marylebone Public Libraries.)

78 Stephen L, ed. Dictionary of national biography. Vol 3. London: Smith Elder 1885:324-5.

79 Burrows EH. A history of medicine in South Africa. Cape Town: Balkema, $1958 ; 89-95 ; 105 ; 112$

80 Bevan M, ed. Dr fames Barry (1795?-1865) inspector-general of military hospitals a bibliography. Johannesburg: Johannesburg Public Library, 1966.

81 Kirby KR. The centenary of the death of James Barry MD inspector-general of hospitals (1795-1865). African Notes and News 1965;16:223-38.
hes

82 Kirby KR. Dr James Barry, controversial South African medical figure; a recent evaluation of his life and sex. S Afr Med F 1970;44:506-16.

83 Assorted papers. London: Wellcome Tropical Institute Archive. Royal Arm Medical Corps collection; catalogue Nos $238 ; 373 ; 454 ; 455 ; 505 ; 658 ; 748 ; 985$; $992 ; 1069 ; 1264$

84 Anonymous. A medico-literary causerie: the evolution of the medical woman The Practitioner 1896; LVI:288-92;407-12.

85 Anonymous. Medical education of women. Br Med $\mathcal{J} 1894 ;$;i: 491.

86 Anonymous. Medical school admissions: report of a formal investigation into St George's hospital medical school. London: Commission for Racial Equality, 1988.

87 Lowry S, Macpherson G. A blot on the profession. Br Med f 1988;296:657-8.

88 Allen I. Any room at the top? A study of doctors and their careers. London: Policy Studies Institute, 1988.

89 Martin P. Women: do they make the best doctors? London Evening Standard Magazine 1988;Aug 5:10-2.

\section{ANY QUESTIONS}

\section{How carcinogenic is bonfire smoke?}

If I were a pedant I would say that before I could answer this question I needed to know what was on the bonfire, how wet the material was, whether it was closely or loosely packed, and whether the day was windy, still, dry, or humid. All these variables influence the extent to which organic materials are completely combusted to non-carcinogens or incompletely combusted (pyrolysed) to a range of molecules, some of which have been shown to be carcinogenic in animal tests. A pedant would also point out that carcinogenic risk varies with exposure and dose so that a goodly blaze in a monodirectional breeze, which took the smoke straight over the garden fence in the direction of your unloved neighbour's washing line, might expose the bonfire maker to no carcinogens at all.

All organic materials when pyrolysed give rise to a variety of known carcinogens. The list includes carcinogenic polycyclic aromatic hydrocarbons-for example, 3,4-benzopyrene-carcinogenic heterocyclic compounds, and a variety of carcinogenic nitrosamines, nitrosamides, and compounds of other chemical types. In addition, the presence of chlorinated compounds in the material being burnt may lead to the generation of various chlorinated compounds, some of which, such as $2,3,7,8$-tetrachlorodibenzo-p-dioxin, are potent enhancers of cancer risk through a variety of non-genotoxic mechanisms. Aldehydes such as acrolein in bonfire smoke cause acute irritation of mucous membranes, and such irritation, which of itself is probably without chronic health risk, serves to protect even bonfire addicts from biologically important exposure to the carcinogens in bonfire smoke.

The blackness of the smoke from some bonfires is due to the presence of carbon (soot) particles and is an indicator of incomplete combustion. In so far as carbon absorbs toxic gases it is not appropriate to imagine that black smoke is more dangerous than white or translucent smoke. Also, the big black particles that land on your washing from next door's bonfire are minimal health hazards because they are too big to penetrate further into the respiration tree than your nose.

So this non-pedant's answer to the question is: provided that you do not stand too close to the down wind side of a bonfire and you are not suffering unduly from the irritant effects of the smoke the low levels of carcinogens present in the smoke are unlikely to have more than an immeasurably small effect on your risk of developing any form of cancer. - FRANCIS J C ROE, independent consultant in toxicology, London

For several years a middle aged woman has suffered from dry painful eyeballs on waking. What might be the cause of this and what treatment is advised?

The history of dry painful eyeballs on waking suggests inadequate lubrication. Tear production decreases during sleep ${ }^{1}$ and if already reduced may give rise to nocturnal or early morning symptoms. In addition the patient may also be experiencing uncomfortable, gritty eyes during the day, which would support the diagnosis. Symptoms may also be worse when there is increased tear evaporation in windy, dry, or airconditioned environments or after reading, when the blink reflex is suppressed. If other mucous membranes are affected the patient may also experience problems such as a dry mouth or dyspareunia. This suggests Sjögren's syndrome, and there may be other associated inflammatory connective tissue disorders. Occasionally, oral treatments such as $\beta$ blockers and drugs with anticholinergic actions may diminish tear flow and exacerbate symptoms. ${ }^{23}$

Treatment is primarily aimed at enhancing ocular lubrication. Simple eye ointment $B P$ at night may provide enough lubrication to ameliorate the morning symptoms. If there are symptoms of dry eye during the day replacement tear drops may also be used as often as necessary. The patient may also benefit from having any associated blepharitis treated.

If simple measures fail to relieve the symptoms the patient should be referred to an ophthalmologist for a more detailed assessment and treatment such as acetylcysteine eye drops for mucus aggregation, punctal occlusion, methylcellulose inserts, and contact lenses. - P T KHÄ, senior registrar in ophthalmology, Landon

1 De Roetth A Sr. Lacrimation in normal eyes. Arch Ophthalmol 1953;49:185-9.

Aberg G, Adler G, Wikberg J. Inhibition and facilitation of lacrimal flow by beta-adrenorecepter drugs. Acta Ophthalmol 1979;57:225-35.

3 Fraunfelder FT. Drug induced ocular side-effects and drug interactions. 2nd ed. Philadelphia: Lea and Febiger, 1982 